\title{
Measuring Germany's Transition to a Green Economy
}

\author{
Christian Lutz ${ }^{*}$, Roland Zieschank ${ }^{2}$, Thomas Drosdowski ${ }^{1}$ \\ ${ }^{1}$ Institute of Economic Structures Research (GWS mbH), Osnabrück, Germany \\ ${ }^{2}$ Environmental Policy Research Centre (FFU), Free University Berlin, Berlin, Germany \\ Email: *lutz@gws-os.de
}

How to cite this paper: Lutz, C., Zieschank, R. and Drosdowski, T. (2017) Measuring Germany's Transition to a Green Economy. Low Carbon Economy, 8, 1-19. https://doi.org/10.4236/lce.2017.81001

Received: January 14, 2017

Accepted: March 11, 2017

Published: March 14, 2017

Copyright (c) 2017 by authors and Scientific Research Publishing Inc. This work is licensed under the Creative Commons Attribution International License (CC BY 4.0).

http://creativecommons.org/licenses/by/4.0/

\section{cc) (i) Open Access}

\begin{abstract}
This paper reports on results of the study entitled "Green economy: Measuring sustainable welfare using SEEA data". It contributes to measuring the progress towards a green economy and to making it accessible for policymaking in Germany. The concept used to measure the green economy looks at six dimensions: 1) use of natural resources and environmental damage caused, 2) natural capital, 3) environmental quality of life, 4) green economy: Economic dimension and fields of action, 5) policies: Institutional framework and measures, and 6) background information on economic and social development. For each dimension the concept includes indicators. The concept fulfils two main purposes: Firstly, it is designed to monitor progress towards a green economy ex-post and secondly some of the proposed indicators can be used to assess policy options ex-ante. Scenario analysis (PANTA RHEI model) is used to apply the concept to Germany's energy transition. Many indicators will improve until 2030 despite some trade-offs.
\end{abstract}

\section{Keywords}

Green Economy, Measurement Concept, Sustainable Welfare, Indicators, Modelling, Energy Transition, System of Environmental-Economic Accounting

\section{Introduction}

The alarming reports on global climate change and the state of the Earth's ecosystems [1] [2] coincided with a global economic and financial crisis in 2008 that was both sudden and painful. This "double crisis" in both the economy and the environment [3] has intensified the search for solutions aiming at a socially and environmentally sustainable economy that goes beyond simple growth strategies ([4] [5] [6]). The idea of a green economy has emerged as a promising strategy. 
It would be driven by public and private investments that reduce carbon emissions and pollution, enhance energy and resource efficiency, and prevent the loss of biodiversity and ecosystem services, as defined by the United Nations Environment Programme [7]. Although conservative in nature due to its reliance on markets and technology [8], this detailed and thorough report provided an important foundation for the Rio +20 summit in 2012, during which representatives from 191 countries discussed the green economy in the context of sustainable development and poverty eradication. The meeting concluded with a UN resolution "The Future We Want", in which the international community officially acknowledged for the first time that a green economy can enhance our ability to manage natural resources sustainably and with fewer negative environmental impacts, increase resource efficiency and reduce waste. However, it has not yet resulted in any international commitments, as [9] emphasized in his critique.

As reflected by [10], the understanding of what constitutes a green economy is far from universally shared, with ideas ranging from business-as-usual to allchange strategies. Under the German Environment Ministry's definition [11], the term green economy describes an economic strategy that protects the climate, continually reduces harmful emissions and pollutant inputs into the environment, practices closed-cycle waste management with a view to creating a circular economy, reduces the use of resources in absolute terms and acts consistently in harmony with nature and the environment. The concept of the green economy creates a positive connection between the environment and the economy to increase social welfare and advance social justice. The concept is regarded as an example of environmentally responsive economic development. It requires an action plan for the goods, labor and financial markets with regard to both supply and demand that considers the needs of all social and economic stakeholders [11]. For a recent overview of green economy concepts see [12].

Additionally, a green economy is meant to help decrease the risk level which affects natural, social and economic capital [13]. The risks posed by climate change, the loss of biodiversity, overfishing, ocean acidification and the increasing water scarcity are endangering social welfare in many regions worldwide. The OECD also recognizes the policy challenges associated with these problems. Hence, when risk minimization is taken into account, the conflict between the environment and the economy no longer exists in its fundamental form [14].

Previous efforts by political and economic agents to move towards a green economy have not measured progress in a systematic and consistent way. In this paper, we present a measurement concept based on a large set of indicators that has evolved from the current discussion of the green economy and how to measure sustainable welfare. It also includes a model analysis of the likely impacts of the energy transition in Germany up to 2030 as a first practical application of the concept. It is largely based on the study "Green Economy: Measuring sustainable welfare using the System of Environmental and Economic Accounting (SEEA) data" [15]. 
Our concept is based on environmental welfare and on a critical review of existing approaches. It can be used to inform environmental policymaking and societal transformation strategies. The analytical focus is on the economy and environment dimensions and their interrelationships. With regard to the environment, the most important issues and fields of action are considered and linked to environmental pressures caused by economic activities both on the output side (e.g. domestic production) and the expenditure side (e.g. private consumption) and the changes to the state of the environment they trigger. Furthermore, the measurement concept takes into account the social aspects of a green economy when they are related to environmental or economic impacts. In addition, this concept also explicitly accounts for the natural asset base. Moreover, it includes further elements of welfare measurement such as interfaces between the environment and health as well as justice.

The concept fulfils two main purposes. Firstly, it includes six interrelated dimensions with their respective indicator groups, including a number of new indicators in all dimensions, designed to monitor progress towards a green economy ex-post. However, the concept is not intended to describe interrelationships between specific indicators or aggregate them. The indicators can be based on actual or estimated data, while at the same time some aspects of the concept necessitate new information. Secondly, an assessment of policy options is possible with some of the proposed indicators ex-ante. An initial model-based application of the concept analyzing the future impacts of Germany's energy transition is presented. It highlights some of the possible interrelationships, which depend to some extent on what policies are actually implemented. The concept is a significant tool to practically monitor and manage long-term transformation.

The article is divided into four sections. Section 2 below briefly discusses existing measurement concepts and examines whether they can be applied to the concept presented here. Section 3 then introduces the actual concept for measuring progress towards a green economy. In section 4, results of an application for modelling Germany's energy transition or Energiewende are presented, focusing mainly on data availability and validity of a chosen subset of indicators. It is important to note that the requirements for national documentation of changes towards a green economy and the requirements for a scenario analysis looking at particular fields of action and environmental policy instruments are different and cannot fully be integrated. Finally, section 5 looks at conclusions, further applications of the indicator concept and future lines of research.

\section{Approaches for Measuring Progress towards a Green Economy}

In this section, existing (including model-based) approaches to measuring progress towards a green economy are briefly discussed (see [15], p. 51 for further detail). The assessment points out the extent to which the green economy and welfare measurement are addressed by existing studies in a way that goes beyond narrow economic measurement and a small number of environmental indica- 
tors. The analysis highlights approaches that improve ways of measuring a green economy by incorporating new aspects that constitute a genuinely "green" economy or at least use new indicators.

The synopsis clearly shows that the indicators so far available for the green economy have rarely been differentiated to address a more comprehensive notion of welfare. In addition, the indicator sets for welfare measurement that are based on GDP are not universally designed to deal with processes towards a green economy in a more detailed way.

The approaches used in the IN-STREAM research project [16], by the European Commission ("I Grow Green") and [17], which are all based on comprehensive sets of indicators, are extremely important as a basis for building indicator systems and modelling applications. They are especially valuable for modelling applications in Germany [4] and the Netherlands [18]. Although the Dutch Statistical Office's indicator set, which is based on the OECD green growth approach, neglects the social dimension of economic and environmental development, it can serve as a basis for comparison. This also applies to the indicator set the Federal Statistical Office developed for Germany based on OECD guidelines, which are briefly discussed later in this section. The Stiglitz report [19] is one of the most important approaches in the context of a new measurement of welfare. However, until now, this mainly conceptual approach has not included many environmental indicators, since it was never intended to be used to measure a green economy.

Some existing modelling approaches are particularly relevant to the application presented in section 4. Among them, a study carried out by [20] improves economic-environmental modelling, but remains quite conventional in terms of the indicators used. Due to its inclusion of the international dimension and utilization of very detailed environmental indicators, the approach used by the Swiss Federal Office for the Environment ([21]) gives new insights that are relevant for the concept presented in section 3.

Due to the rationale of their construction, composite indicators such as Adjusted National Savings (ANS, [31]) and the National Welfare Index (NWI, [22]) as aggregated figures are not suitable for implementation in a complex indicator system, particularly because some of their monetary valuations are still very tentative. However, some subcomponents of the indices are informative with regard to the economic costs of damage caused by environmental pressures. Other studies aiming to adjust the GDP-based assessment of welfare-with composite indicators such as ISEW [23] and GPI [24] are not further followed in this analysis, because they are based on the same aggregated monetary index rationale. Nevertheless, these concepts of economic, environmental and social welfare generate important inputs for designing the framework of a green economy indicator system, as described in the next section.

Finally, approaches to ecosystem services research, in particular the international TEEB studies [25] are promising. However, in their current state they have only been conceptually included in the indicator system for measuring a 
green economy, since there are still no empirical indicators available at national level.

Against the background described in section 1, we shall look in more detail at two approaches that could provide conceptual-theoretical input for a concept of measuring a green economy and ideas for increasing welfare. The first approach stems from the OECD initiative for fostering green growth [14], in which it is acknowledged that the pursuit of green economic growth has to be very closely linked to an indicator set allowing documentation of the transformation process itself and of its anticipated successes. Accordingly, it has suggested an extensive set of sub-indicators at international level to support reporting by interested countries [17]. Germany's Federal Statistical Office has undertaken a more concrete implementation, presenting an indicator set based on OECD guidelines [4]. Here most of the green growth indicators chosen by the OECD were implemented in a statistically adequate way, primarily using data from the System of Environmental and Economic Accounting (SEEA). The quality of the indicators and their relation to specific sectors of the green economy make them a good basis for further analyses.

In the conceptual structure underlying the OECD approach, inputs (labor, capital, natural assets and environmental services) are transformed in production processes into goods that are demanded by other businesses, consumed by households or exported. It is important that natural assets in particular be used economically and efficiently in order to contribute to green economic growth. At the same time, it is crucial that emissions, waste and environmental pressures in general are reduced. The individual parts of the OECD system (economy, environment and policies) are connected to four groups of indicators that cover (1) environment and resource productivity, (2) natural capital, (3) environmental quality of life, and (4) economic opportunities and political responses. The SEEA indicator set, applied to Germany using the OECD concept, covers numerous single indicators for each of these groups [4].

The second building block in creating a concept for measuring a green economy is a study that was part of the project "Basic points of an environmentally acceptable welfare concept as a foundation for environmental policy innovation and transformation processes" [1] [26] [27]. The results of this study serve as a conceptual framework to identify and structure the different dimensions and indicators for measuring a green economy. Thus, a sustainable welfare concept consists of a descriptive component that includes the complex interrelationships between the environmental, economic and social systems, along with a normative component in which the alternatives for action can be located and assessed based on politically, administratively, ethically and socially established goals.

Within this concept, the notion of social welfare goes beyond the traditional understanding, i.e. economic growth and an increase in GDP as the basis of wealth, by including material and immaterial components of social prosperity [28] This means that welfare results from the combined use of economic goods and infrastructure (real economic and financial capital), skills and relationships 
in society (human and social capital) and the available wealth of a country in the form of resources, ecosystems and their functions (natural capital) [29]. In this sense, nature is recognized as an explicit productive factor and not only as a natural resource, as advocated for example by [30].

A concept of this kind requires that welfare is optimized (i.e. the achievement of economic and social goals) on the condition that important environmental objectives are achieved. Above all, this necessitates a strategy of absolute decoupling of environmental pressures from economic development. As measuring a green economy is understood to be an ambitious task, involving contributions towards achieving environmental goals, the question of appropriate indicators and reference values arises.

In addition to the main parts on which the intended measurement of a green economy can be based on the one hand, categories with indicators suggested by the OECD and, on the other hand, the new conceptual frame of an environmental welfare model some theoretical assumptions and conceptual ideas from research on the political economy and environmental policy are included.

Overcoming the environmental problems caused by economic processes will be a central component of a modern welfare concept, if natural capital is taken into account as a crucial basis for social well-being and progress [30] [31]. The hypothesis can therefore be supported that the modern welfare state is based on regulating and on overcoming at least in part social and ecological risk situations. From this, several conclusions can be drawn which go beyond the OECD approach and simultaneously fit well into the view of social welfare as an increase in economic, social and natural capital and can be used to develop a concept for measuring a green economy. The main conclusion is that nature and the environment should become an integral component of an economic accounting system. Supporting arguments for this integration are included in [32]. A stronger inclusion of the production functions of nature (ecosystem services) is very challenging, however [33].

The environmental damage caused by production and consumption activities in a country and the costs of violating environmental limits have to be accounted for as an integral component. Otherwise it is not possible to measure how green an economy actually is. An amortization of investments that not only have an environmental value but can also generate economic value added for society becomes more likely the further into the future the time horizon is extended. The demand for an intelligent overall accounting method with an adequate indicator system that illustrates the long term physical environmental pressures and reliefs at national level can be developed from this.

This rationale ultimately results in a green economy being understood in terms of socioeconomic development processes in the economic system and intensive interaction with the policymaking system, taking into account the limits of environmental sustainability, although these limits are defined more or less strictly in different studies (e.g. [34] [35]). Hence, the green economy is both a development process and a transformation process that is strongly influenced by 
policymaking.

\section{Description of the Concept}

The proposed measurement concept has six different dimensions and corresponding groups of indicators and also includes socioeconomic framework data: 1) natural resource use and environmental damage, 2) natural capital, 3) environmental quality of life, 4) green economy: economic dimension and fields of action, 6) policies: institutional framework and measures, and 6) background information on economic and social development.

Figure 1 illustrates the concept; it is related to the OECD's green economy concept, but contains new dimensions and interrelationships between the main dimensions. The six individual dimensions indicated with capital letters are linked to groups of indicators.

On a more abstract level, the core concept consists of two main dimensions: the economy and the environment, which have diverse interrelationships. The environment is important for the socioeconomic sector, especially in its function as a resource, sink or producer (or carrier) of ecosystem services. In the "traditional" socioeconomic system, only natural resources and the production factors

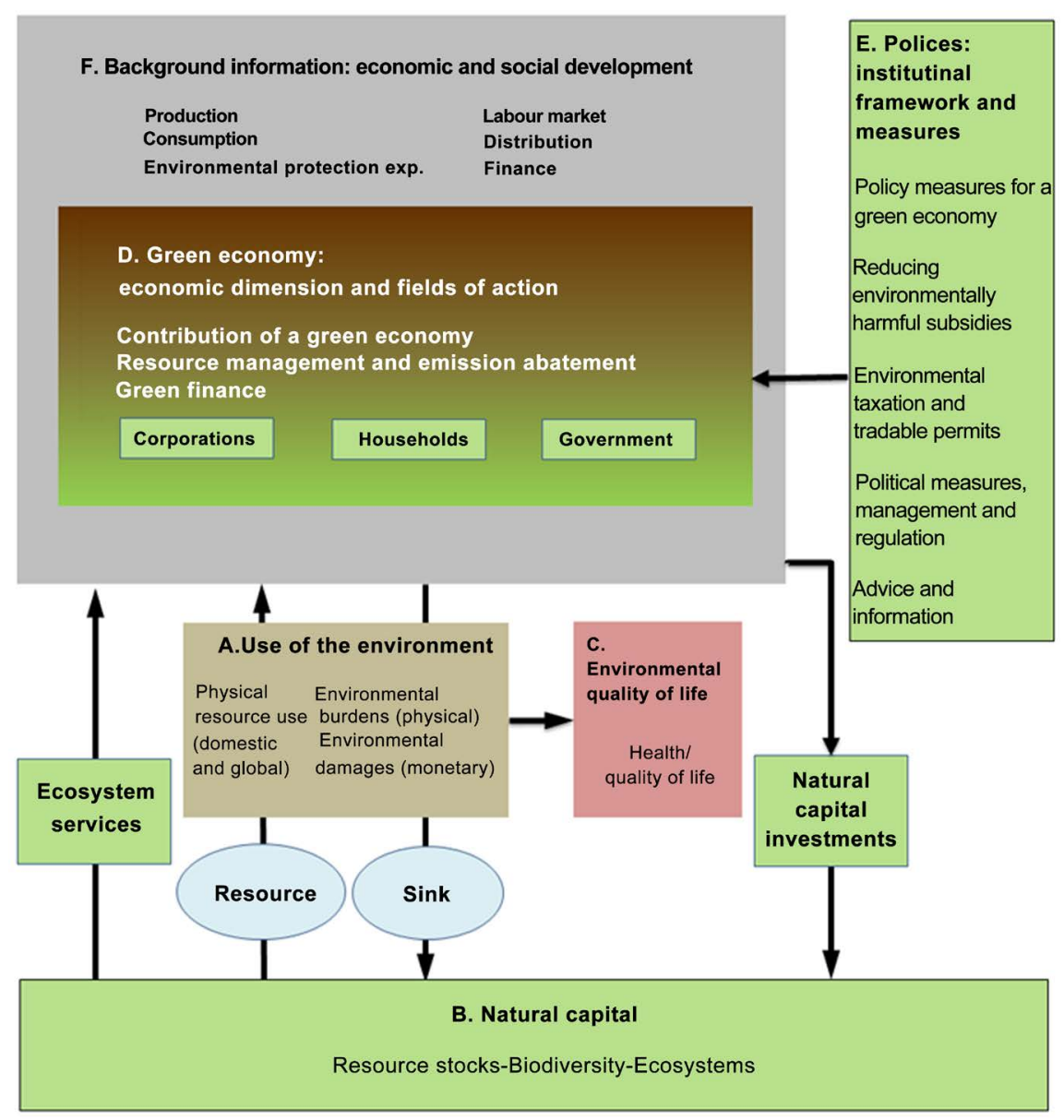

Figure 1. Concept for measuring progress towards a green economy. 
labour and real capital provided by private households are transformed into goods and services in production processes. Additionally, financial capital that can be transformed into real capital originates from company profits, the financial sector (e.g. private equity funds) or the central banks, has now become a new driving force that can generate economic activities. Both production and consumption cause significant harmful environmental impacts as a result of resource extraction, physical interventions in nature and landscape, and emissions.

The logic underlying the concept is reflected by a broad set of around 100 indicators selected on the basis of existing measuring approaches. The indicators are or should, if no data exists at the moment, be mainly aggregated figures for Germany. They are proportional figures, i.e. refer to the national level or are percentage shares. Some of them are marked as "core indicators" due to their special importance and publicity.

The core indicators were selected on the basis of whether they can be connected to specific environmental policy goals so that directional reliability concerning their interpretation is ensured and the information value of practical applications can be increased. Furthermore, they can generally be considered to be sufficiently established, as indicated by broad-based literature reviews, or they have been tested by statistical offices or are part of officially published sets of indicators. Compatibility with international indicator concepts is an additional advantage. The foundation is in part established by the SEEA data that was used to test the green growth approach in Germany [4]. Certain indicators that are well founded conceptually can currently not be calculated due to data limitations. They are marked as desired indicators, which may be provided by public institutions in the medium or long term.

The following detailed description of the concept by individual dimensions is supported by examples of indicators. It is important to stress that the indicators are neither linked to each other in a causal way nor can be aggregated without further assumptions. This would require a complete understanding of all interrelationships and would therefore only be possible using a very complex quantitative model. Hence, the conceptual relationships refer to linkages between single dimensions of the system that contain groupings of indicators. Despite these limitations, the system can be used for monitoring the development towards a more green economy in a country such as Germany.

Dimension A

Economic activities imply the use of domestic (displayed in the indicator Table 1) and global natural resources and at the same time generate pressures on the natural environment, which can be monetized in some cases.

Dimension B

The natural environment is subject to negative changes due to production and consumption patterns that deplete natural resources, put excessive pressure on the capacity of ecosystems, and go beyond their ability to absorb emissions and waste. The stock of natural assets (dimension B) and their quality are reduced or degraded as a result. However, in this understanding of a green economy it is 
possible that some natural capital can be built up by adequate investment. Moreover, the relevant ecosystem functions and services that are important for humans can be secured by maintaining ecosystems. If natural capital is seen as a major element in the welfare of the economy and society, investments designed to foster natural capital (examples of indicators are given in Table 2) will likewise be seen as valuable and important for the future.

Due to environmental modernization processes and economic structural change, the use of resources, emissions and excessive stress on ecosystem services can be reduced while natural capital, on the one hand, and the environmental quality of life, on the other, can be maintained or in some cases increased. The extent to which the costs of environmental damage and of rectifying it can be accounted for is important, if a society is to improve its welfare [22]. It cannot be assumed, however, that environmental degradation processes and damage can in all cases be reversed.

\section{Dimension C}

Meanwhile, the intensive use of nature and the pressures generated, in particular by emissions, do not only reduce natural stocks and potential. They are also harmful to humans, having a negative impact on health and quality of life (dimension C). Furthermore, questions of distributional and social justice and ethical considerations are also relevant due to the differences in vulnerability between social groups. This is true for both physical and financial aspects. In principle, these questions would also have to include the intergenerational dimension [36].

\section{Dimension D}

The activities of private and public companies and of consumers also have a decisive influence on the transformation process towards a green economy that

Table 1. Indicators of dimension A: physical resource use (domestic).

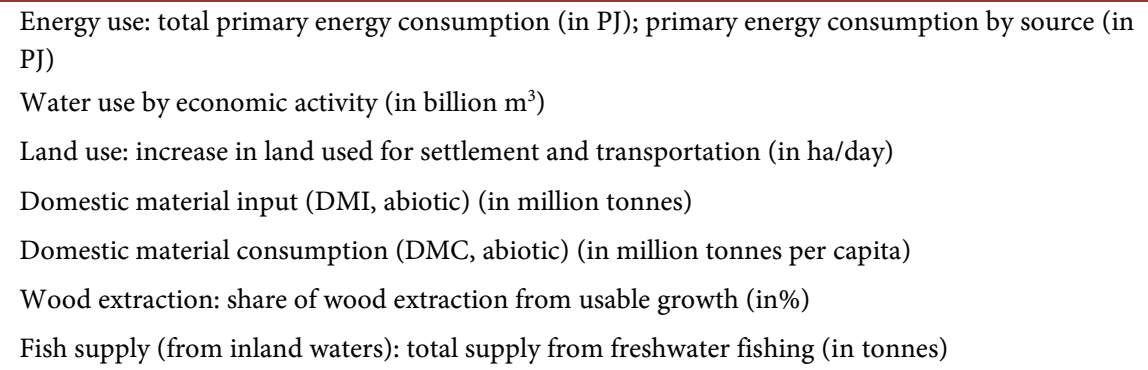

Table 2. Indicators of dimension B: natural capital investments.

Expenditure on nature conservation: investment and running expenses for nature and landscape conservation (in billion euros)

Protected areas: designation of new protected areas (in $\mathrm{km}^{2}$ )

Agricultural environmental protection measures: EU and government subsidies (in euros spent per $\mathrm{km}^{2}$ of land)

Expenditure for "green corridors" for biotope networking (in billion euros)

"Green" foreign aid: share of environmental foreign aid in total foreign aid (in\%) 
takes place within the economic system (dimension D). Environmental modernization measures and modified consumption habits indicate the growing economic importance of green sectors and their ability to increase value added, for example. This progress is not limited to the environmental protection industry but also involves the classical economic sectors and their interrelationships. In particular, the adoption of measures to increase resource and energy efficiency and lower emissions in these sectors, which in many cases is not policy-driven, is key to mainstreaming environmental aspects and results in an expansion of the green economy. At the same time, there is growing awareness that the classical division into "green" and "brown" sectors of the economy has become obsolete and many classical sectors such as steel production or engineering can now play a central role in shaping the green economy (e.g. [37]). Table 3 shows the indicators pertaining to resource management and emission abatement.

The financial economy plays an important, albeit ambivalent, role in these processes. On the one hand, "green finance" provides a basis for environmental investment and innovation as private small and wholesale investors, such as pension funds, increasingly base their investments on environmental criteria. According to [38], the funding problem poses the second most important challenge for the green economy alongside the need for markets, policymakers and

Table 3. Indicators of dimension D: resource management and emission abatement.

Sectoral energy use: primary energy use by industry (in PJ)

Energy productivity: GDP to primary energy use ratio (index)

Share of renewable energy in total energy use (in\%)

Share of renewable energy in electricity consumption (in\%)

$\mathrm{CO}_{2}$ productivity: ratio of GDP to energy-induced $\mathrm{CO}_{2}$ emissions (index)

Waste treatment: shares of main waste streams (in\%)

Recycling: share of material utilization in total waste (in\%)

Utilization of harmful substances: share of harmful substances treated (in\%)

Material productivity: ratio of GDP to domestic material consumption (DMC, non-energetic) (index)

Water productivity: water intensity by industry (in $\mathrm{m}^{3} / 1000$ euros of gross value added)

Transport volume (passengers) (in passenger-kilometers)

Transport volume (freight) (in tonne-kilometers)

Modal split in passenger transport: breakdown of passenger transport volume by mode of transport based on passenger-kilometers (in\%)

Modal split in freight transportation: breakdown of freight transport volume by mode of transportation based on tonne-kilometers (in \%)

Organic farming: share of agricultural land farmed organically (in\%)

Share of integrated environmental protection in total environmental protection investment (in\%)

Diffusion of "green" management systems in companies: number of companies certified under EMAS and ISO 14,001 
institutions to address sustainability. On the other hand, the financial markets still tend to disregard environmental aspects in their profit-maximizing calculus. This is especially important in times of financial crisis, as disruptions to the financial markets' core functions endanger the realisation of important environmental projects.

Dimension E

The transformation towards a green economy depends on institutional frameworks and measures (E) that offer incentives for companies and households and directly affect the production and consumption sphere. Ideally, environmental policy measures trigger a change in business activities and the behaviour of the public, consisting of private consumers and social stakeholders. In this respect, the green economy is ultimately a result of the interrelationships between economic stakeholders, institutional frameworks and measures, along with consumers and civil society stakeholders.

Dimension $\mathrm{F}$

Finally, the transition to a green economy has to be seen in relation to further economic and social developments such as employment rate or more conventional indicators such as GDP (F). Such important background information is not directly part of the measurement concept, but it helps to put developments into context.

In this section, the indicator set of six dimensions to monitor progress towards a green economy ex-post has been presented. In the next section a model-based analysis of the impacts of energy transition in Germany up to 2030 is a first application of the concept. It highlights some of the possible interrelationships, which partly depend on the policies implemented.

\section{Application: Modelling Energy Transition in Germany}

Some of the indicators for which sufficient data was available have been applied to the case of Germany's energy transition. Green economy indicators are not directly correlated. Instead, two scenarios are implemented in the PANTA RHEI economy-energy-environment model, which includes some of the measurement concept's indicators as endogenous variables. Changes in the indicators between two different model solutions are traced back to policy measures, which translate into different assumptions on policy variables as model inputs. The Current Policies Scenario (CPS) takes all measures into account that were implemented up to 8 July 2011, when a revision of Germany's Energy Concept came into force following the Fukushima accident. The Energy Transition Scenario (ETS) also includes additional measures that contribute to the German Government achieving its climate change mitigation goals by 2030. These additional measures are mainly in energy efficiency, as policy targets for renewable energy in electricity production will already be reached in the CPS scenario. The comparison of the measurement concept's indicators across the two scenarios reveals changes due to the energy transition in the different dimensions of the concept. It also shows future needs for indicators that are not yet statistically available and for 
further improvements to the modelling technique.

The simulations were taken from the study "Economic evaluation of climate protection measures and instruments of different policy scenarios" commissioned by the Federal Environmental Agency [39]. The policy scenarios for climate protection VI [40] are the basis for analysing the effects of the climate change mitigation measures. Differences between the indicators in both scenarios can be traced back to the measures under the ETS scenario.

PANTA RHEI is an extended version of the macroeconometric simulation and forecasting model INFORGE, designed to analyse questions in environmental economics. The name, a quotation from the Greek philosopher Heraclites, means "everything flows" and sums up our approach perfectly. It models longterm structural change in economic development and in environmental-economic interdependencies. In addition to comprehensive economic modelling, it also includes energy consumption, air pollution, transport, land use and housing to a high level of detail. A detailed description of the economic part of the model is presented in [41] [42] [43]. It has been used for the economic evaluation of the German energy transition within the monitoring process [44]. Applications also include energy efficiency policies [39] [45] and the impact on employment of promoting renewable energy [46].

The behavioural equations of the model reflect bounded rationality rather than optimizing behaviour of agents. All parameters are estimated econometrically from time series data from 1991 to 2010. Producer prices are the result of companies' mark-up calculations. Output decisions follow observable historic developments, including observed inefficiencies rather than optimal choices. The use of econometrically estimated equations means that agents have only myopic expectations and follow routines developed in the past. This implies that, in contrast to optimization models, markets will not necessarily be in an optimum state and non-market (energy and environmental) policy interventions can have positive economic impacts.

Most of the concept's indicators projected in the model stem from the economic dimension and fields of action dimension (D). Some indicators from different categories of the natural resource use and environmental damage dimension (A) are also endogenous to the model. One indicator belongs to the policies: institutional framework and measures dimension (E). Many indicators are part of the background information on the economic and social development dimension (F). However, indicators from the environmental quality of life dimension (C) are not part of the model and could not be used for the application. The situation regarding measures from the natural capital dimension (B) is also unsatisfying. However, including indicators for natural gas, carbon and wood stock is at least possible. Any "desired indicator" that was not included in the application has simply not yet been provided by the statistics offices or other comparable institutions, but is nevertheless a component of the measurement concept for good reason.

Indicators from dimension A (water utilization, land consumption, wood ex- 
traction, air pollutant emissions and their damage costs) are achievable in the future, provided some advanced modifications are made to the model. Indicators for the macroeconomic importance of the green economy and material productivity that are part of dimension $\mathrm{D}$ can be calculated. It would also be possible to include $\mathrm{CO}_{2}$ emission allowances as well as further background information.

Compared to the CPS scenario, the ETS scenario would need additional investment of between 25 and 40 billion euros annually [45]. This investment would concentrate on cost-effective energy efficiency measures, particularly on modernizing building insulation. As a result, the gross domestic product in the ETS scenario is 24 to 30 billion euros higher than in the CPS scenario. Positive employment effects will reach around 200,000 additional jobs annually. The positive macroeconomic effects of the climate change mitigation measures explored in the ETS scenario appear to be robust with regard to changes of key assumptions. The results confirm findings from other studies about the macroeconomic effects of climate change mitigation measures, in particular those aimed at improving energy efficiency in Germany. Similarly positive macroeconomic results are reported in country studies for Germany ([47] [48]) with annual net annual employment gains of some 100,000 jobs due to additional energy efficiency measures and other countries such as Greece [49] or Japan [50]. An IEA report [51] also highlights the positive impacts of energy efficiency. Furthermore, although there were some difficulties in making detailed comparisons, climate change mitigation measures examined will bring macroeconomic advantages.

Assumptions about crowding out of additional investment in climate change mitigation are important for the magnitude and direction of effects of the energy transition. However, according to [39], even under the extreme assumption of full crowding out, i.e. additional investment in climate change mitigation measures completely replaces other investment, about three quarters of the positive impacts on economic variables of the energy transition will remain in 2030.

Primary effects triggered by the ETS scenario are increased investment in climate change mitigation measures. Capital stock of equipment and construction is about $2 \%$ higher in 2030 , and primary energy consumption is $12.5 \%$ lower, as Table 4 shows. As some expansion of renewable energy is promoted at the same time, its share in the decreasing final energy consumption and in electricity consumption increases (by more than 5 and 6.6 percentage points respectively). All other changes in indicators are triggered by the differences between the scenarios.

The decreasing energy consumption and expansion of renewable energy are caused by a reduction in fossil fuel use in production processes. This results in a significant additional decrease in greenhouse gas emissions by more than 16 per cent. The costs of carbon, calculated as $\mathrm{CO}_{2}$ emissions multiplied by damage costs per tonne, which have been estimated by the Federal Environmental Agency for 2030, are reduced by almost 16 billion euros (-19 per cent). Domestic material inputs increase by 1.9 per cent with higher investment.

The energy transition improves the cost efficiency of the national economy. 
Table 4. Impact of energy transition on selected green economy indicators in 2030.

\begin{tabular}{|c|c|c|}
\hline Indicator & $\begin{array}{l}\text { Absolute } \\
\text { difference }\end{array}$ & $\begin{array}{c}\text { Percentage } \\
\text { deviation }\end{array}$ \\
\hline \multicolumn{3}{|l|}{$\begin{array}{l}\text { Dimension A: natural resource use and } \\
\text { environmental damages }\end{array}$} \\
\hline Primary energy consumption (in PJ) & -1426 & -12.5 \\
\hline Domestic material input (in million tonnes) & 23.0 & 1.9 \\
\hline Greenhouse gas emissions (index, $1990=100$ ) & -8.7 & -16.4 \\
\hline Damages caused by $\mathrm{CO}_{2}$ emissions (in billion euros) & -15.7 & -19 \\
\hline \multicolumn{3}{|l|}{$\begin{array}{l}\text { Dimension D: green economy: economic dimension and } \\
\text { fields of action }\end{array}$} \\
\hline Energy productivity (index, $1990=100)$ & 28.6 & 14.4 \\
\hline Share of renewable energy in total energy use (in \%) & 5.4 & 21.7 \\
\hline Share of renewable energy in electricity consumption (in \%) & 6.6 & 12.8 \\
\hline $\mathrm{CO}_{2}$ productivity (index, $1990=100$ ) & 74.8 & 24.8 \\
\hline \multicolumn{3}{|l|}{$\begin{array}{l}\text { Dimension E: policies: institutional framework and } \\
\text { measures }\end{array}$} \\
\hline Share of environmental taxes in total tax revenue (in \%) & -0.9 & -15.7 \\
\hline \multicolumn{3}{|l|}{$\begin{array}{l}\text { Dimension F: background information on economic and } \\
\text { social development }\end{array}$} \\
\hline Gross domestic product (price adjusted) (in billion euros) & 30.0 & 1.1 \\
\hline $\begin{array}{l}\text { Structure of private consumption expenditure (in \%): expend- } \\
\text { able goods }\end{array}$ & -0.8 & -2.8 \\
\hline $\begin{array}{l}\text { Structure of private consumption expenditure (in \%): } \\
\text { non-durable and durable goods }\end{array}$ & 0.7 & 3.8 \\
\hline Structure of private consumption expenditure (in \%): services & 0.1 & 0.2 \\
\hline Capital stock (price adjusted, index, $2000=100$ ): equipment & 3.6 & 2.1 \\
\hline Capital stock (price adjusted, index, $2000=100$ ): construction & 3.0 & 2.1 \\
\hline Unemployment rate (in\%) & -0.3 & -8.2 \\
\hline Public debt: debt-to-GDP ratio (in\%) & -4.7 & -6.7 \\
\hline
\end{tabular}

Source: authors' own calculations with the model PANTA RHEI [39].

The higher level of investment boosts the capital stock by approximately 2 per cent. In addition, private consumption increases by 3.1 billion euros, or 0.2 percentage points. In total, the annual increase in GDP adjusted for price changes amounts to nearly 30 billion euros. This is accompanied by higher employment and lower unemployment rate. The question as to whether the recorded effects of the measures in the Energy Transition Scenario (ETS) contribute to a green economy can be answered positively with only a few trade-offs. This is firstly due to the limited number of the indicators from the measurement concept considered. Secondly, some of the indicators such as domestic material consumption-do not change in the direction desired. This example shows clearly that the scenario measures do not represent a "one-size-fits-all" policy. A reduction of material consumption, for example, has to be addressed with further policy measures. However, for the other reported indicators, a consistent transforma- 
tion progress was seen. Applying the PANTA RHEI model to Germany's energy transition shows mainly positive results for a subset of indicators. An inclusion of further indicators will improve model-based evaluation in the future.

\section{Conclusions and Outlook}

Transformation of the existing economy into a green economy is a promising strategy for ensuring that environmental policies are effective in addressing problems caused by production and consumption processes before they arise rather than retrospectively. This transformation requires (1) a longer transitional phase to allow social, political and economic learning processes to take place, (2) processes of readjustment, realignment and restructuring, and (3) consideration of the consequences for foreign trade relations and foreign policy in general in a green economy.

Such a complex process needs to be underpinned by systematic information systems for policymakers and the administration both in Germany and beyond. The strategic importance of an indicator system for measuring a green economy means that reporting and appropriate accounting should be undertaken on a regular basis since this is the only way to record and discuss positive and negative trends.

The concept described here fulfils two main purposes. Firstly, the indicator set includes six dimensions to monitor progress towards a green economy ex-post. The measurement concept goes beyond what is currently the state of the art by including the social aspect of sustainability, explicitly accounting for the natural asset base and containing a large number of indicators in all dimensions, some of them new. The concept itself is not intended to describe interrelationships between indicators or aggregate them. Secondly, an assessment of policy options is possible with some of the proposed indicators ex-ante. The paper therefore includes a model-based analysis of the likely impacts of the energy transition in Germany up to 2030 as a first practical application of the concept. It highlights some of the interrelationships, which to some extent depend on the policies implemented. The application of the set of indicators to scenario simulations using the PANTA RHEI model shows mainly positive impacts of the Energy Transition Scenario compared with the Current Policies Scenario for those indicators that are endogenous to the model. The application also reveals gaps in the understanding of interrelationships, the model and the statistical availability of indicators.

The study is limited regarding data availability. The concept has to be further discussed and harmonized on national and international level: It would be useful to develop a more detailed national green economy indicator set, initially being challenging in terms of currently available data. Subsequently, this broad concept could be put forward for discussion with other countries or in international forums. Finally, the set of indicators developed or a similar concept for measuring progress towards a green economy should be adopted at global level. Monitoring is essential to measure progress towards a green economy at international 
level. Currently, several international organizations are looking for measurement concepts that can be applied in practice in an international context. The concept described in section 4 could be a good basis.

Future research should focus on filling the gaps in the existing indicator set with regard to ecosystem services, accounting for natural capital and social investments in nature and ecosystems, developing governance indicators or environmental cost estimations related to quality of life or costs of illness caused by air pollutants and in the field of social indicators, e.g. by evaluating ongoing studies. A comparison of results over a specific period could also be valuable. While the application presented in section 4 about the energy transition including its modelling was applied ex-ante, ex-post comparison is also conceivable.

To support and monitor the achievement of Sustainable Development Goals [35] the measurement concept is to be extended to sustainable welfare, more economic and social sectors, financial, human and social capital, and advanced international aspects. The approach presented here can be expanded to include these aspects. The transition towards a Green Economy needs to be accelerated and a radical transformation is required, however ([52] [53]).

\section{References}

[1] Rockström, J., Steffen, W., Noone, K., Persson, Å., Chapin, F.S., Lambin, E.F., Lenton, T.M., Scheffer, M., Folke, C., Schellnhuber, H.J., Nykvist, B., de Wit, C.A., Hughes, T., van der Leeuw, S., Rodhe, H., Sörlin, S., Snyder, P.K., Costanza, R., Svedin, U., Falkenmark, M., Karlberg, L., Corell, R.W., Fabry, V.J., Hansen, J., Walker, B., Liverman, D., Richardson, K., Crutzen, P. and Foley, J.A. (2009) A Safe Operating Space for Humanity. Nature, 461, 472-475. https://doi.org/10.1038/461472a

[2] Steffen, W., Richardson, K., Rockström, J., Cornell, S.E., et al. (2015) Planetary Boundaries: Guiding Human Development on a Changing Planet. Science, 347, 6223. https://doi.org/10.1126/science.1259855

[3] Bina, O. and La Camera, F. (2011) Promise and Shortcomings of a Green Turn in Recent Policy Responses to the "Double Crisis". Ecological Economics, 70, 2308 2316. https://doi.org/10.1016/j.ecolecon.2011.06.021

[4] German Federal Statistical Office (2013) Test of the OECD set of Green Growth Indicators in Germany. Wiesbaden.

[5] Hertwich, E.G. and Peters, G.P. (2009) Carbon Footprint of Nations: A Global, Trade-Linked Analysis. Environmental Science \& Technology, 43, 6414-6420. https://doi.org/10.1021/es803496a

[6] Wiedmann, T., Schandl, H., Lenzen, M., Moran, D., Suh, S., West, J. and Kanemotoc, K. (2013) The Material Footprint of Nations. Proceedings of the National Academy of Sciences of the United States of America, 112, 6271-6276. https://doi.org/10.1073/pnas.1220362110

[7] UNEP (2011) Towards a Green Economy: Pathways to Sustainable Development and Poverty Eradication.

[8] Brockington, D. (2011) A Radically Conservative Vision? The Challenge of UNEP's towards a Green Economy. Development and Change, 43, 409-422. https://doi.org/10.1111/j.1467-7660.2011.01750.x

[9] Barbier E.B. (2012) The Green Economy Post Rio+20. Science, 338, 887-888. https://doi.org/10.1126/science.1227360 
[10] Bina, O. (2013) The Green Economy and Sustainable Development: An Uneasy Balance? Environment and Planning C: Government and Policy, 31, 1023-1047. https://doi.org/10.1068/c1310j

[11] Federal Ministry for the Environment, Nature Conservation and Nuclear Safety (BMU) (2012) Green Economy. New Impetus for Sustainability, Berlin.

[12] Loiseau, E., Saikku, L., Antikainen, R., Droste, N., Hansjürgens, B., Pitkänen, K., Leskinen, P. Kuikman, P. and Thomsen M. (2016) Green Economy and Related Concepts: An Overview. Journal of Cleaner Production, 139, 361-371. https://doi.org/10.1016/j.jclepro.2016.08.024

[13] World Bank (2011) The Changing Wealth of Nations: Measuring Sustainable Development in the New Millennium, Environment and Development.

[14] OECD (2011a) Towards Green Growth. http://www.oecd.org/greengrowth/48224539.pdf

[15] Lutz, C., Zieschank, R. and Drosdowski, T. (2015) Green Economy: Nachhaltige Wohlfahrt Messbar Machen unter Nutzung der umweltökonomischen Gesamtrechnungs-(UGR) Daten. Umweltbundesamt Texte 69.

[16] Bosello, F., Portale, E., Campagnolo, L., Eboli, F. and Parrado, R. (2011) Sustainability Index Analysis, FP7 ENV 2007.1-WP6: Costs of Sustainability (General Equilibrium Analysis)—Deliverable 6.5.

[17] OECD (2011b) Towards Green Growth: Monitoring Progress: OECD Indicators. OECD Publishing.

[18] Statistics Netherlands (2011) Green Growth in the Netherlands. The Hague/ Heerlen.

http://www.cbs.nl/en-GB/menu/themas/macro-economie/publicaties/publicaties/ar chief/2011/2011-green-growth-pub.htm

[19] Stiglitz, J., Sen, A. and Fitoussi, J.-P. (2009) Report by the Commission on the Measurement of Economic Performance and Social Progress. Paris.

[20] Jäger, C.C., Paroussos, L., Mangalagiu, D., Kupers, R., Mandel, A. and Tàbara, J.D. (2011) A New Growth Path for Europe-Generating Prosperity and Jobs in the Low-Carbon Economy. Synthesis Report, Potsdam.

[21] Federal Office for the Environment (FOEM) (2011) Environmental Impacts of Swiss Consumption and Production. A Combination of Input-Output Analysis with Life Cycle Assessment. Bern.

[22] Diefenbacher, H., Zieschank, R., Held, B. and Rodenhäuser, D. (2013) NWI 2.0-Executive Summary. Heidelberg and Berlin.

[23] Daly, H.E. and Cobb, J.B. (1994) For the Common Good: Redirecting the Economy toward Community, the Environment, and a Sustainable Future. 2nd Edition, Beacon Press, Boston.

[24] Kubiszewski, I., Costanza, R., Franco, C., Lawn, P., Talberth, J., Jackson, T. and Aylmer, C. (2014) Beyond GDP: Measuring and Achieving Global Genuine Progress. Ecological Economics, 93, 57-68. https://doi.org/10.1016/j.ecolecon.2013.04.019

[25] TEEB Report (2010) The Economics of Ecosystems and Biodiversity: Ecological and Economic Foundations. London.

[26] Ahlert, G., Meyer, B., Zieschank, R. and Diefenbacher, H. (2014) Basic Structures and Political Implications of a Sustainable Welfare Model. Journal of Environmental Science and Engineering, A3, 189-203.

[27] Meyer, B., Ahlert, G., Zieschank, R. and Diefenbacher, H. (2013) Eckpunkte eines 
ökologisch tragfähigen Wohlfahrtskonzeptes. Study III as Part of the Project Entitled "Eckpunkte eines ökologisch tragfähigen Wohlfahrtskonzepts als Grundlage für umweltpolitische Innovations- und Transformationsprozesse" Carried out for the Federal Ministry for the Environment, Nature Conservation and Nuclear Safety (BMU). GWS Research Report 2013/1, Osnabrück, Heidelberg and Berlin.

[28] Fritz, M. and Koch, M. (2014) Potentials for Prosperity without Growth: Ecological Sustainability, Social Inclusion and the Quality of Life in 38 Countries. Ecological Economics, 108, 191-199. https://doi.org/10.1016/j.ecolecon.2014.10.021

[29] Zieschank, R. and Diefenbacher, H. (2012) The National Welfare Index as a Contribution to the Debate on A More Sustainable Economy. FFU-Report 02-2012, Forschungszentrum für Umweltpolitik, FU Berlin.

[30] Dasgupta, P. (2008) Nature in Economics. Environmental and Resource Economics, 39, 1-7. https://doi.org/10.1007/s10640-007-9178-4

[31] German Advisory Council on the Environment (SRU) (2012) Environmental Report 2012-Responsibility in a Finite World. Summary for Policy Makers, Berlin.

[32] Bartelmus, P. (2015) Do We Need Ecosystem Accounts? Ecological Economics, 118, 292-298. https://doi.org/10.1016/j.ecolecon.2014.12.026

[33] Kallis G., Gómez-Baggethun, E. and Zografos, C. (2013) To Value or Not to Value? That Is Not the Question. Ecological Economics, 94, 97-105.

https://doi.org/10.1016/j.ecolecon.2013.07.002

[34] Hayer, M., Nilsson, M., Raworth, K., et al. (2015) Beyond Cockpitism: Four Insights to Enhance the Transformative Potential of the Sustainable Development Goals. Sustainability, 2015, 1651-1660.

[35] United Nations (2014) Synthesis Report of the Secretary-General on the Post-2015 Agenda: The Road to Dignity by 2030: Ending Poverty, Transforming All Lives and Protecting the Planet. New York.

[36] Diefenbacher, H., Zieschank, R., Duewell, M., Leggewie, C., Petschow, U., Philips, J., Pissarskoi, E. and Sommer, B. (2014) Konzepte gesellschaftlichen Wohlstands und ökologische Gerechtigkeit. Study Commissioned by the Federal Environment Agency, Umweltforschungsplan des Bundesministeriums für Umwelt, Naturschutz und Reaktorsicherheit: Schwerpunkt 12. Übergreifende umweltpolitische Forschungsfragen. Forschungskennzahl $3711 \quad 11$ 103. Umweltbundesamt Reihe Texte 14/2014.

http://www.umweltbundesamt.de/sites/default/files/medien/378/publikationen/text e_45_2014_konzepte_gesellschaftlichen_wohlstands.pdf

[37] World Steel Association (2012) Sustainable Steel. At the Core of the Green Economy. Brussels.

http://www.worldsteel.org/en/dam/jcr:5b246502-df29-4d8b-92bb-afb2dc27ed4f/Sus tainable-steel-at-the-core-of-a-green-economy.pdf

[38] Barbier, E.B. (2011) The Policy Challenges for Green Economy and Sustainable Economic Development. Natural Resources Forum, 35, 233-245. https://doi.org/10.1111/j.1477-8947.2011.01397.x

[39] Lutz, C., Lehr, U. and Ulrich, P. (2014) Economic Evaluation of Climate Protection Measures in Germany. International Journal of Energy Economics and Policy, 4, 693-705.

[40] Matthes, F., Busche, J., Döring, U., Emele, L., Gores, S., Harthan, R., Hermann, H., Jörß, W., Loreck, C., Scheffler, M., Hansen, P., Diekmann, J., Horn, M., Eichhammer, W., Elsland, R., Fleiter, T., Schade, W., Schlomann, B., Sensfuß, F. and Ziesing, H., et al. (2013) Politikszenarien für den Klimaschutz VI- 
Treibhausgas-Emissionsszenarien bis zum Jahr 2030. Climate Change 04/2013, Dessau-Roßlau.

http://www.umweltbundesamt.de/publikationen/politikszenarien-fuer-den-klimasc hutz-vi

[41] Lutz, C. and Lehr, U. (2014) Macroeconomic Effects of Renewable Energy and Energy Efficiency Policies with a Focus on Germany. In: Bernhard, L. and Semmler, W., Eds., The Oxford Handbook of the Macroeconomics of Global Warming, Oxford University Press, Oxford, 477-496.

[42] Lehr, U. and Lutz, C. (2016) German Energiewende-Quo vadis? In: Bardazzi, R., Pazienza, M.G. and Tonini, A., Eds., European Energy and Climate Security: Public Policies, Energy Sources, and Eastern Partners, Springer, Berlin, 203-232. https://doi.org/10.1007/978-3-319-21302-6_10

[43] Maier, T., Mönnig, A. and Zika, G. (2015) Labour Demand in Germany by Industrial Sector, Occupational Field and Qualification Until 2025-Model Calculations Using the IAB/INFORGE Model. Economic Systems Research, 27, 19-42. https://doi.org/10.1080/09535314.2014.997678

[44] GWS, EWI and Prognos (2014) Gesamtwirtschaftliche Effekte der Energiewende. Study Commissioned by the Federal Ministry for Economic Affairs and Energy. Osnabrück, Cologne and Basel. http://www.bmwi.de/DE/Mediathek/publikationen,did=662814.html

[45] Lehr, U., Lutz, C. and Ulrich, P. (2013) Gesamtwirtschaftliche Wirkungen von Klimaschutzmaßnahmen und -instrumenten: Politikszenarien für den Klimaschutz VI. Climate Change 21/2013, Dessau-Roßlau.

[46] Lutz, C., Lehr, U. and Edler, D. (2012) Green Jobs? Economic Impacts of Renewable Energy in Germany. Energy Policy, 47, 358-364.

https://doi.org/10.1016/j.enpol.2012.04.076

[47] Blazejczak, J., Edler, D. and Schill, W.-P. (2014) Improved Energy Efficiency: Vital for Energy Transition and Stimulus for Economic Growth. DIW Economic Bulletin, 4, 3-15.

[48] Kuckshinrichs, W., Kronenberg, T. and Hansen, P. (2010) The Social Return on Investment in the Energy Efficiency of Buildings in Germany. Energy Policy, 38, 4317-4329. https://doi.org/10.1016/j.enpol.2010.03.060

[49] Markaki, M., Belegri-Roboli, A., Michaelides, P., Mirasgedis, S. and Lalas, D.P. (2014) The Impact of Clean Energy Investments on the Greek Economy: An Input-Output Analysis (2010-2020). Energy Policy, 57, 263-275. https://doi.org/10.1016/j.enpol.2013.01.047

[50] Matsuhashi, R. and Takase, K. (2015) Green Innovation and Green Growth for Realizing an Affluent Low-Carbon Society. Low Carbon Economy, 6, 87-95. https://doi.org/10.4236/lce.2015.64010

[51] IEA (2014) Capturing the Multiple Benefits of Energy Efficiency. Paris.

[52] Jänicke, M. (2012) “Green Growth”: From a Growing Eco-Industry to Economic Sustainability. Energy Policy, 48, 13-21. https://doi.org/10.1016/j.enpol.2012.04.045

[53] Mundaca, L., Neij, L., Markandya, A., Hennicke, P. and Jinyue, Y. (2016) Towards a Green Energy Economy? Assessing Policy Choices, Strategies and Transitional Pathways. Applied Energy, 179, 1283-1292.

https://doi.org/10.1016/j.apenergy.2016.08.086 
Submit or recommend next manuscript to SCIRP and we will provide best service for you:

Accepting pre-submission inquiries through Email, Facebook, LinkedIn, Twitter, etc. A wide selection of journals (inclusive of 9 subjects, more than 200 journals)

Providing 24-hour high-quality service

User-friendly online submission system

Fair and swift peer-review system

Efficient typesetting and proofreading procedure

Display of the result of downloads and visits, as well as the number of cited articles Maximum dissemination of your research work

Submit your manuscript at: http://papersubmission.scirp.org/

Or contact lce@scirp.org 